\title{
Aquifer Thermal Energy Storage Application in Greenhouse Climatization
}

\author{
Bekir TURGUT, Halime PAKSOY, Şaziye BOZDAĞ, Hunay EVLIYA, Kazım ABAK, H. Yildiz DASGAN
}

Çukurova University 01130 Balcall Adana-Turkey

bturgut@,cu.edu.tr, hopaksoy@cu.edu.tr,sabaci@,cu.edu.tr, hevliya@,cu.edu.tr, abak@,cu.edu.tr, dasgan@.cu.edu.tr

\begin{abstract}
The aim of this study is to determine the heating and cooling potential of the greenhouses in the Mediterranean climatic zone, with aquifer thermal energy storage (ATES) known as one of the underground thermal energy storage application systems (UTES). In recent years greenhouse production reached to 44.000 ha in Turkey (Abak et all 1995). For high yield and quality in greenhouse crops during the winter months, inside temperature should be maintained at the critical value that can change depending on the species grown in greenhouse. For instance, for tomatoes the critical inside temperature should be maintained not below $12-13{ }^{0} \mathrm{C}$ in the greenhouse. Due to this information and also last 20 year's climate data in Mediterranean Region a greenhouse needs approximately $150 \mathrm{~kW}$ heating load during 90 days in a year, 8 hours in a day (Abak et all.1995). To provide this heating load, $6 \mathrm{~L} / \mathrm{m}^{2}$ No 6 Fuel-Oil or $9 \mathrm{~kg} / \mathrm{m}^{2}$ coal must be consumed. The fossil fuel consumption leads to an economic burden in the operating cost, besides ashes and undesirable gas emissions from coal combustion are the biggest barriers of the greenhouses in the Mediterranean zone. Additionally, the cooling requirement of the greenhouses for early autumn and spring months in the Mediterranean Climate and the advantages provided after cooling applications will be calculated.
\end{abstract}

For these purposes, two separate greenhouses, each having an area of $360 \mathrm{~m}^{2}$, in the research area of the Horticulture Department - Faculty of Agriculture have been selected. One of them was heated and cooled by ATES technique (Figure 1). In the second one conventional heating system was used and there was no cooling system. Tomato and eggplant plants were grown in the greenhouses. But only tomato's results are presented in this paper. Consequently, these two different systems/greenhouses were compared in terms of economical, environmental and agricultural aspects.

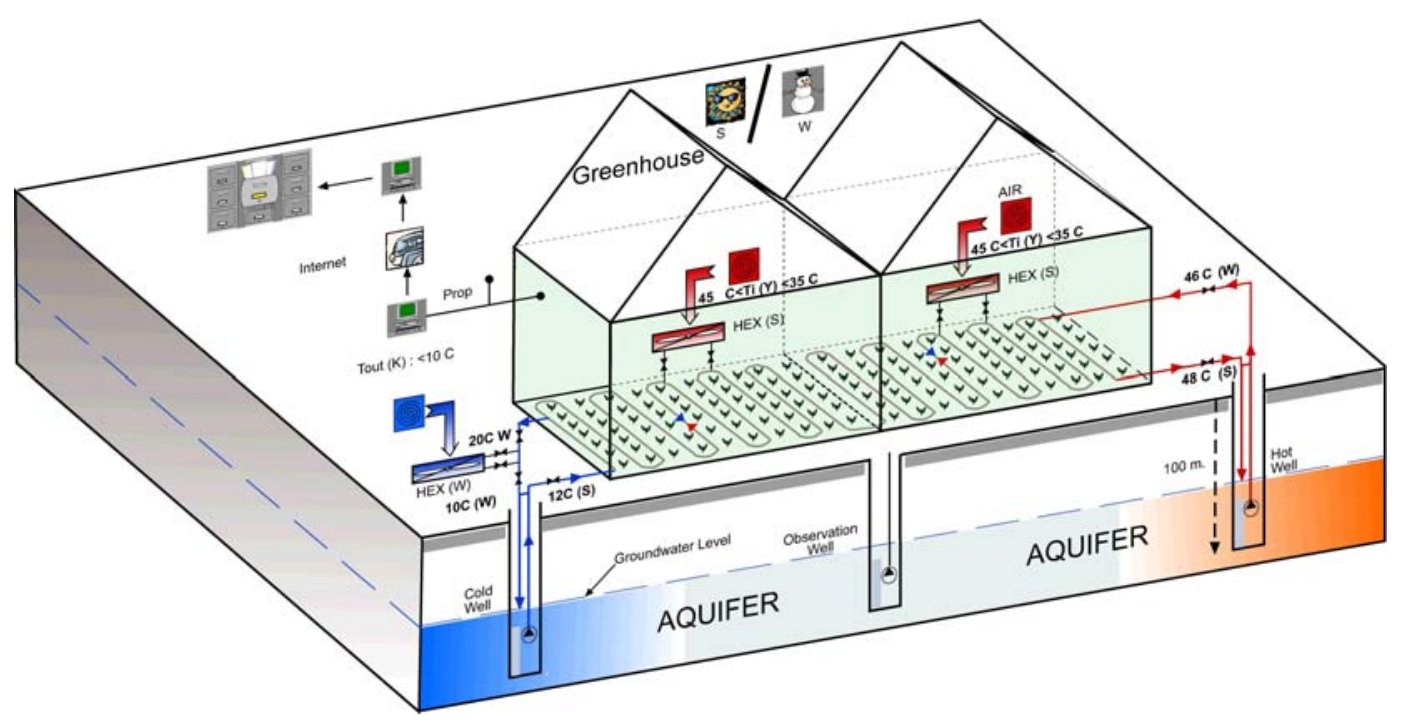

Figure 1: Basic concept of the system 


\section{Introduction}

For heat storage, the idea of the system is using greenhouse as a natural solar collector during the summer months in Mediterranean climates. In side of the greenhouse temperature can be increase during the day time up to $60{ }^{\circ} \mathrm{C}$ when the natural air ventilation windows shut down during the summer months. This waste heat has been stored via fan-coils to the hot well. And this stored energy used for heating during the winter with out any fossil burner for keep the inside air temperature up to $12{ }^{\circ} \mathrm{C}$.

Opposite of the systems is the using out-side ambient temperature during the winter months for cold storage. When out-sides ambient temperature decrease below to $10{ }^{0} \mathrm{C}$ than out side fan-coil stores this energy to cold well. And this stored energy uses for cooling during the spring months.

\section{Well Drilling}

Regarding to the project 2 wells has been drilled, which named TÜBİTAK-K1 (see Figure 2) and TÜBİTAK$\mathrm{K} 2$. The purpose of $\mathrm{K} 1$ is use for cold storage and $\mathrm{K} 2$ is use for heat storage. Each well drilling has been end at 80 meters. During the drilling geological sampling has been done in each meter. Rotary well bit cuts clay, mainly conglomerate and blue clay (see Figure 3). Aquifers are in conglomerate layers.

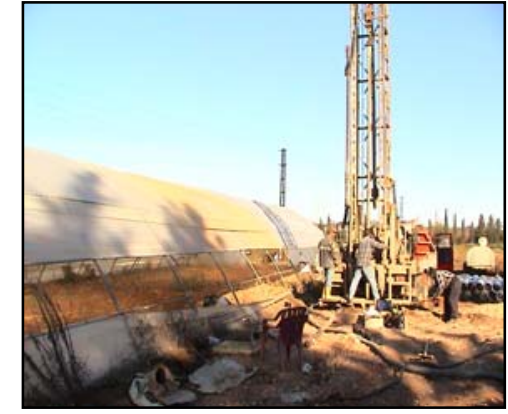

Figure 2: Well drilling

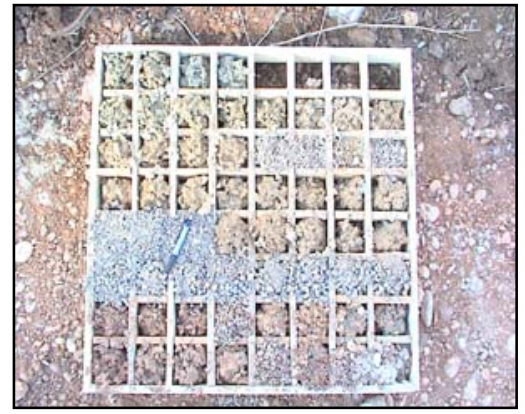

Figure 3: Sampling

\subsection{Geophysical Measurements}

When drilling process finalize in each well, than geophysics measurement in both wells have been done (see Figure 4). Self Potential (SP, $5 \mathrm{mV}$ ), Natural Gamma (GR, $\mathrm{T}_{\mathrm{c}}: 3 \mathrm{GR}: 0.05 \mathrm{mR} / \mathrm{h}$ ) and Resistivity $(\mathrm{R}, 10 \mathrm{ohm} / \mathrm{m})$ measurements has been done. Result has been given in Figure 5.

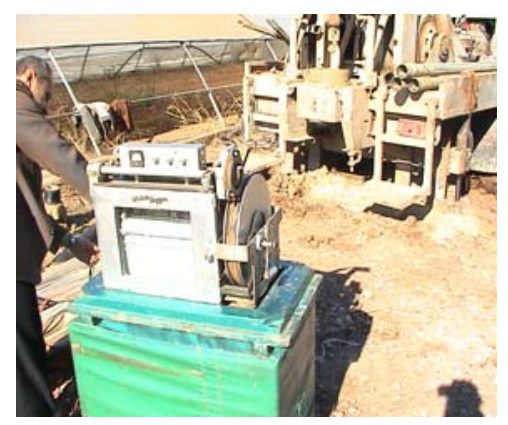

Figure 4: Geophysics measurements

\subsection{Casing and Gravel Pack}

Due to geological sampling while drilling process and geophysics measurements, casing and gravel pack process completed. Due to sieve analysis, 7-10 mm gravels are used in gravel pack. Only 6 meters filtered casing used between 39-45 meters level (see Figure 5). 10" casing pipe has been used in each well (see Figure 6). Also clay band installed between 20-30 meters for hydraulic insulation (see Figure 5). 


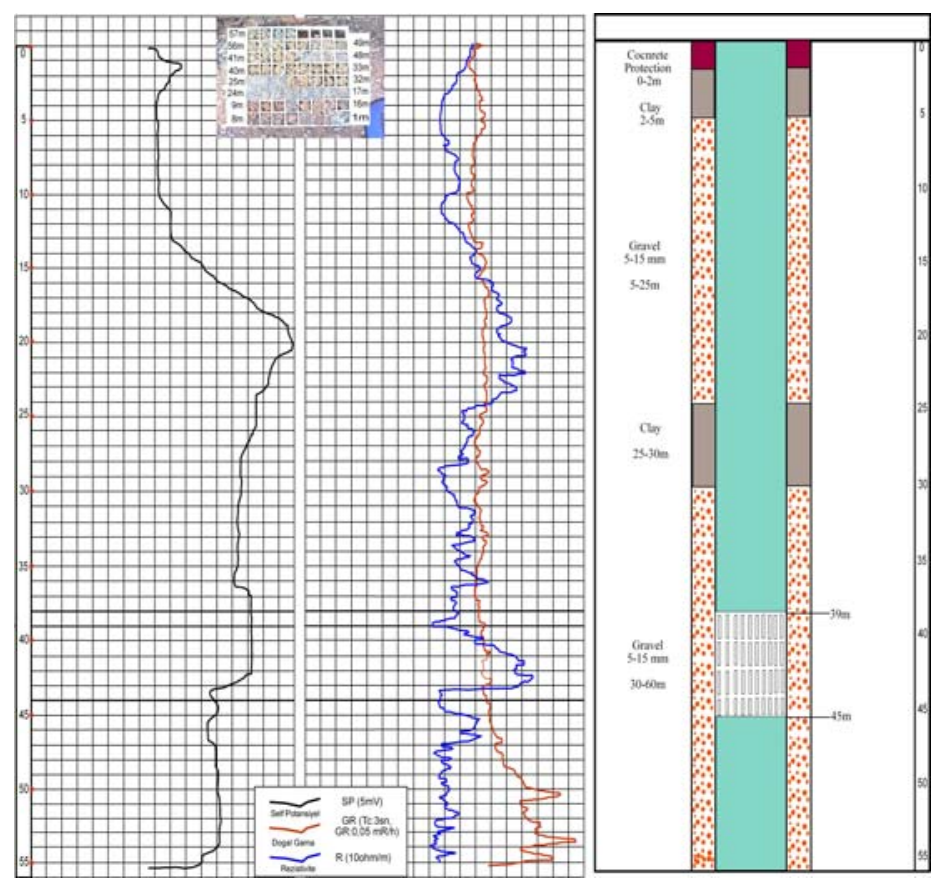

Figure 5: Result of geophysics measurements and casing schema of the well

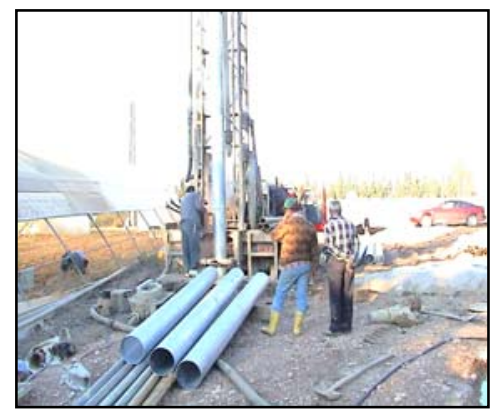

Figure 6: Casing and gravel pack

\section{Pump Test Con-Flow Simulations}

For determination of the hydro-geological capacity of the aquifer, long term pump test has been done (Figure 7). Pump test results used in simulation program. For calculating optimum distance between two wells, con-flow simulation program has been used. Result of the simulation given in Figure 8.

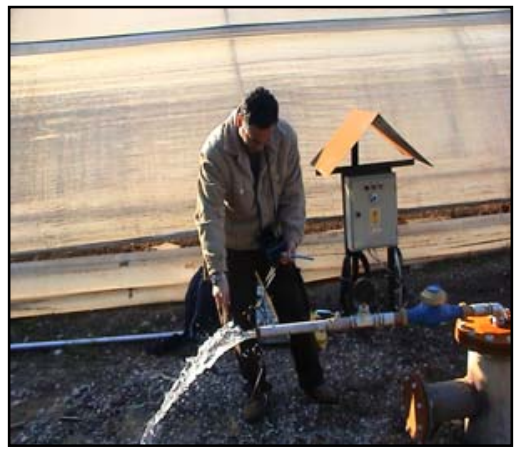

Figure 7: Long term pump test 

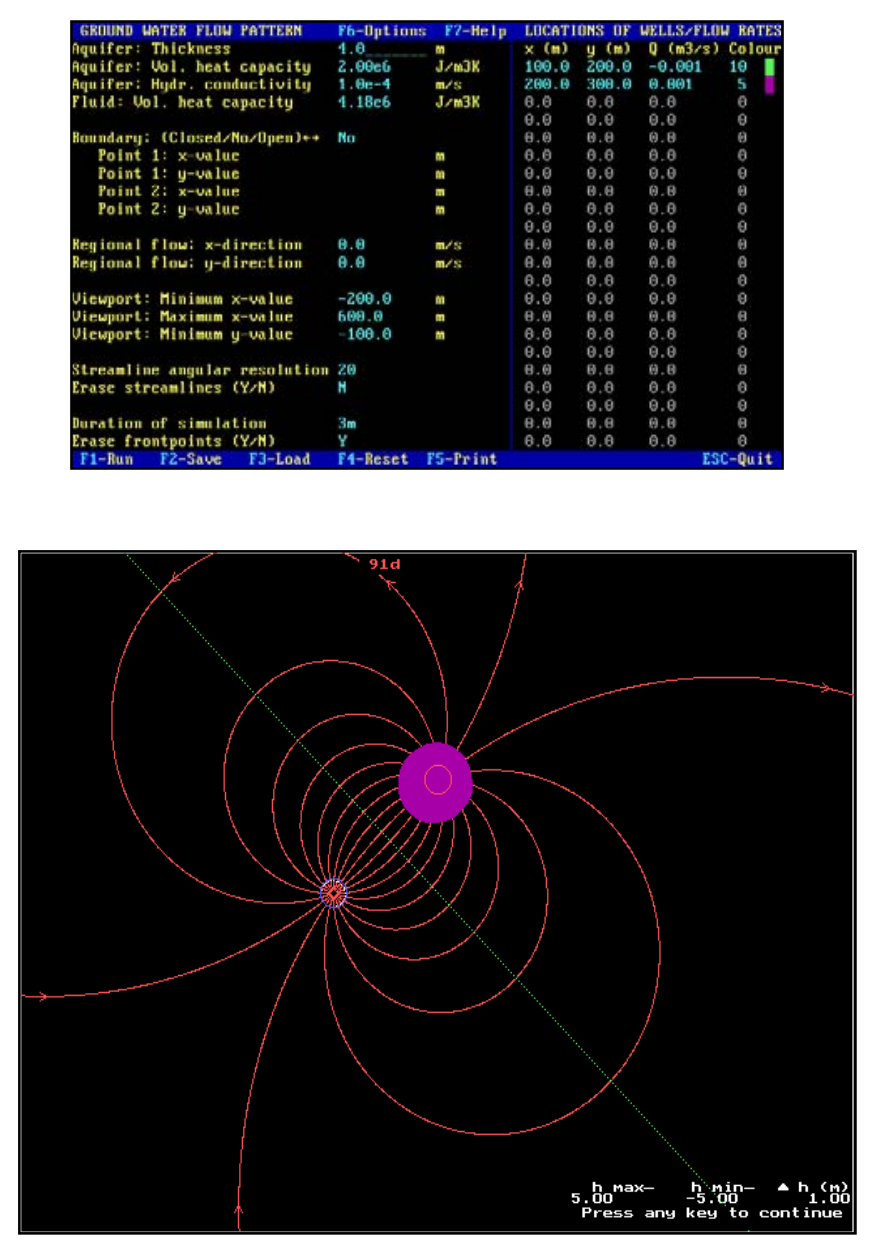

Figure 8: Con-Flow Simulation program

As a result of con-flow simulations optimum distance between two wells finds out 90 meters.

\section{Heat Storage}

In end of June 2005, fan-coils, wells as and automation systems was ready. Heat storage start in June 27 and finished 70 days later. Total energy storage value day by day given in Figure 9. Approximately $100.000 \mathrm{MJ}$ amount of energy has been store. $20{ }^{\circ} \mathrm{C}$ incoming water from cold well heat up to $35{ }^{\circ} \mathrm{C}$ with waste heat and injected to hot wells.

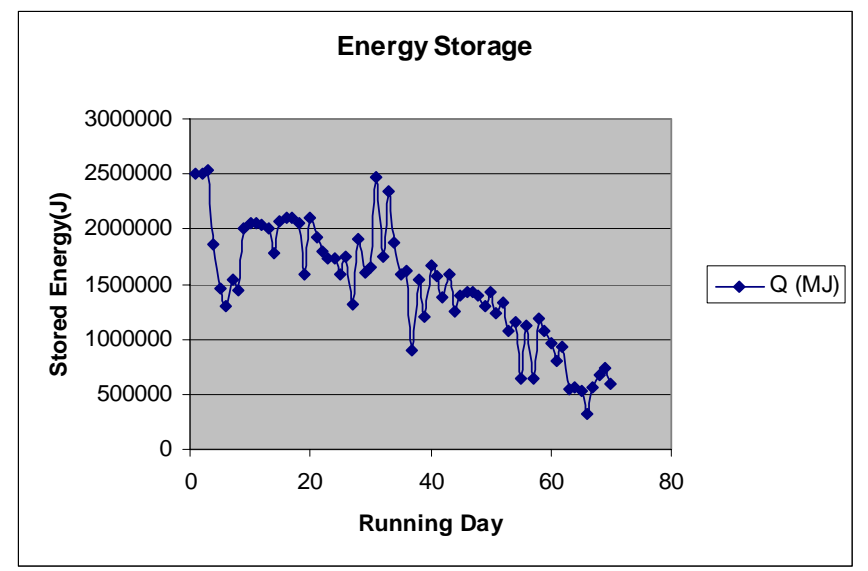

Figure 9: Total energy storage during summer of 2005 


\section{Heat Recovery}

As a system design stored energy is use for heating during the winter month for heating. For tomatoes optimum growing temperature is $12{ }^{\circ} \mathrm{C}$ for winter. Figure 10 shows coldest night which ever measured 2006 winter (June 30, 3006). Dark blue line shows out-side ambient temperature as $\mathrm{T}_{\text {out }}$, yellow line shows control greenhouse temperature as $\mathrm{T}_{\mathrm{in} 2}$, pink line is shows ATES greenhouse temperature as $\mathrm{T}_{\mathrm{in} 1}$ and turquoise line shows plant level temperature as $\mathrm{T}_{\text {plant }}$. This figure shows 24 hour measurements. Start at 9.00 in the morning and finish 9.00 in next morning. As we can see on the graphs as well ATES green house's in side temperature never down to critical temperature even out side temperature below down to $0{ }^{0} \mathrm{C}$. ATES greenhouse inside temperature also keep all night is stabile. Plant temperature also never drop down to critical level as show Turquoise line.

Control green house in side temperature shown as $\mathrm{T}_{\mathrm{in} 2}$ is decrease under critical temperature level till 21.00 and after that point, boiler start up, which consume fuel oil. As a result of that control greenhouse in side temperature reached to critical level.

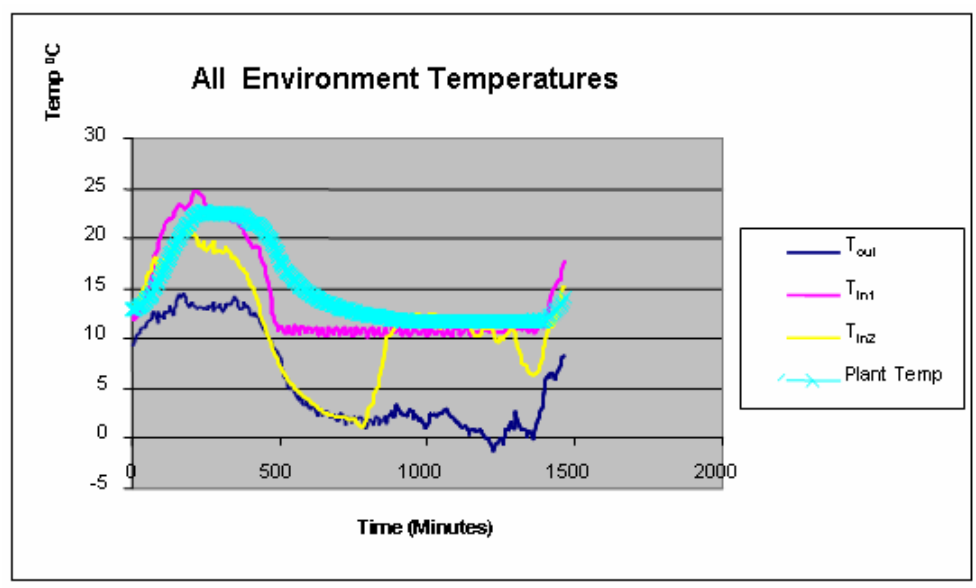

Figure 10: All medium temperatures (Start at June 29, 9.00 o'clock and finish at June 30, 9.00 o'clock)

Figure 11 shows water temperature. When the ATES greenhouse temperature decreases critical level $\left(12{ }^{0} \mathrm{C}\right)$ than automation systems start for heating. Pink line shows hot well water income as W2. Yellow line show cold well out, which pass through the out side fan-coil as W3. W1 and W4 is also shows water temperature in side of the ATES greenhouse. As we can see from pink line hot well income is about $25{ }^{0} \mathrm{C}$ instead of $18-19{ }^{0} \mathrm{C}$. This difference caused by last summer heat storage.

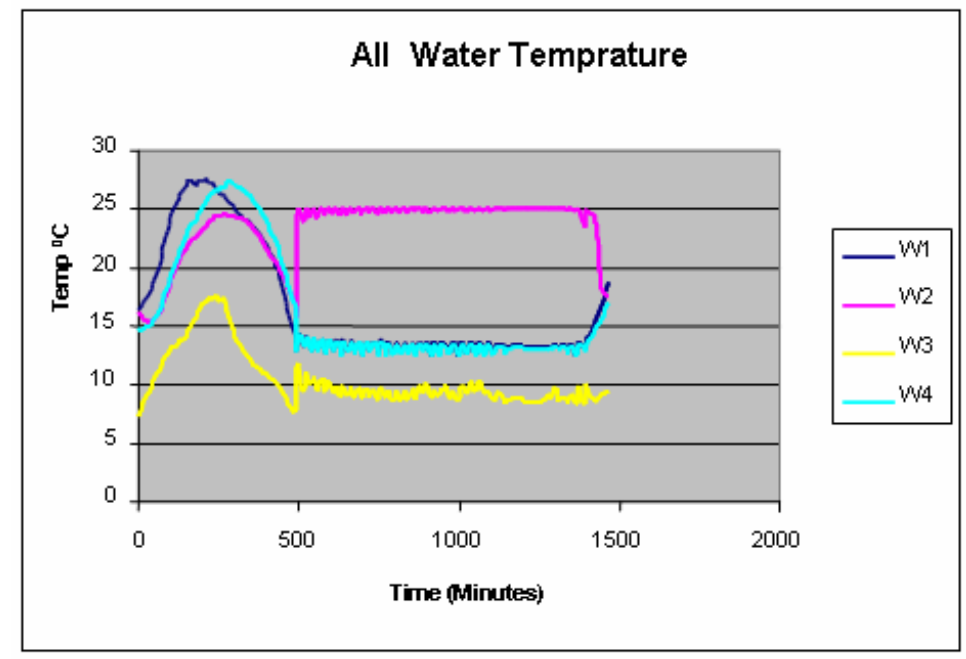

Figure 11: All water temperature (Start at June 29, 9.00 o'clock and finish at June 30, 9.00 O'clock) 


\section{Plant Production}

Planting of tomato seedlings has been realized in September 4, 2005 in both greenhouse. Figure 12 shows planting in control greenhouse. A hybrid cultivar "Terminator F1" was used as plant material. For pollination, in both greenhouse bumble bee colonies have been used (see Figure 13). Figure 14 shows 1 month later after first planting.

For homogenous heat transfer, installed PE chimneys in to the ATES greenhouse (see figure 13, 15).

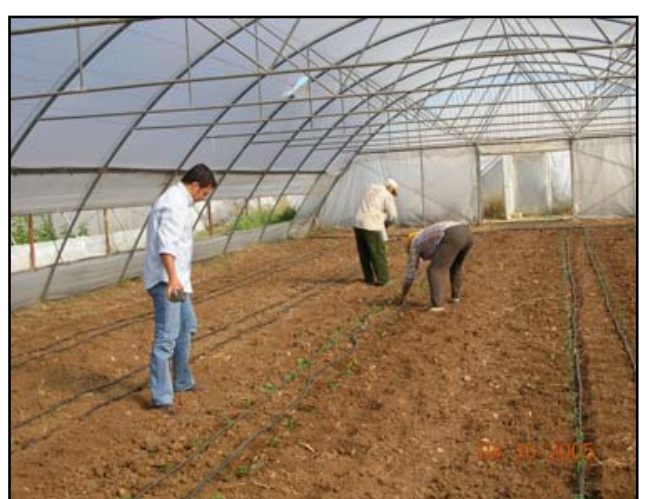

Figure 12: Tomatoes seeds planting in control greenhouse

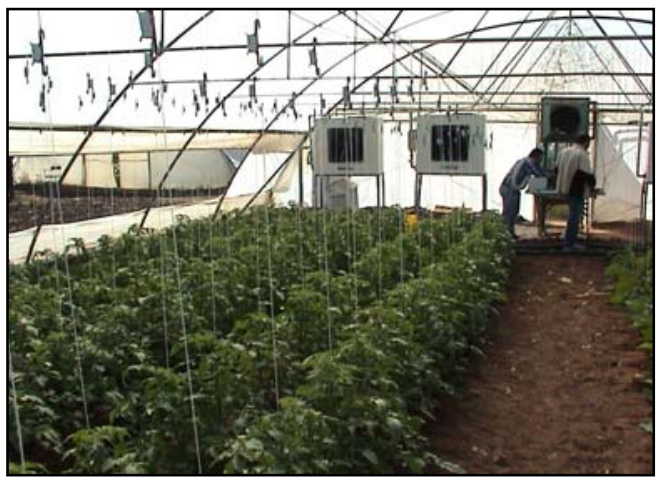

Figure 14: One month later after first planting

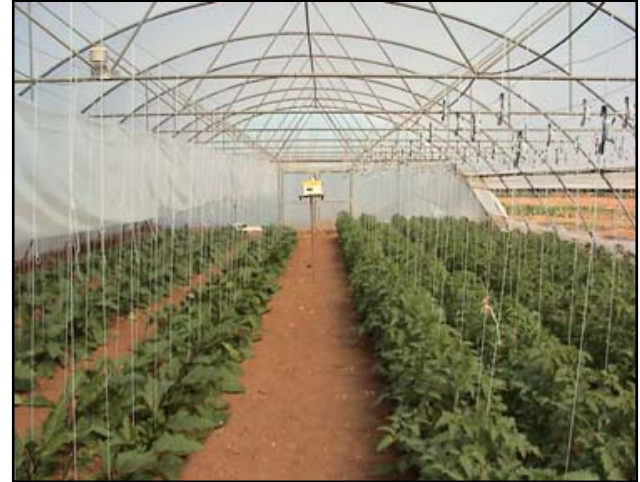

Figure 13: Bumble bees in the greenhouse

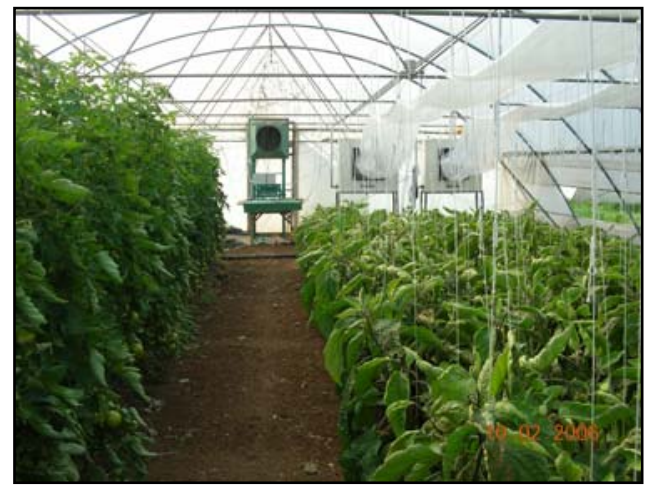

Figure 15: PE chimneys in ATES greenhouse

Heating process has been done during 2005-06 winter growing season with ATES in ATES greenhouse and fuel oil heating used in control greenhouse. In ATES greenhouse, inside temperature never below to critical temperature level. For this performance never use fossil burn. Also some plant growing and plant biomass parameter obtained on tomatoes has been given in Table 1 and 2. These tables are comparative between each other as Aquifer and Control.

Table 1: Plant Growing Parameter (Tomato)

\begin{tabular}{|c|c|c|c|c|c|}
\hline & $\begin{array}{c}\text { Plant } \\
\text { Height } \\
(\mathrm{cm})\end{array}$ & $\begin{array}{l}\text { Number of Leaf } \\
\text { per Plant }\end{array}$ & $\begin{array}{c}\text { Number of Cluster } \\
\text { per Plant }\end{array}$ & $\begin{array}{c}\text { Stem } \\
\text { Diameter } \\
(\mathrm{mm})\end{array}$ & $\begin{array}{c}\text { Avarage Fruit per } \\
\text { Cluster }\end{array}$ \\
\hline Aquifer & $154.87 \mathrm{a}$ & 22.1 & 4.82 & $17.16 \mathrm{a}$ & 5.13 \\
\hline Control & $138.00 \mathrm{~b}$ & 22.1 & 4.47 & $15.96 \mathrm{~b}$ & 5.02 \\
\hline $\begin{array}{c}\text { Differency } \\
(\%)\end{array}$ & 12 & 0 & 8 & 8 & 2 \\
\hline
\end{tabular}

As we can see in Table 1, which shows plant growing parameter, average height of ATES greenhouse's plant is $\% 12$ more than control greenhouse. Number of leaf is same in both greenhouse, but number of cluster and stem diameter were $\% 8$ more than control greenhouse. Average fruit number per cluster is also $\% 2$ more than control greenhouse in ATES greenhouse. 
Table 2: Table 2: Plant Biomass Parameter (Tomato)

\begin{tabular}{|c|c|c|c|c|c|}
\hline & $\begin{array}{c}\text { Plant Fresh } \\
\text { Weight } \\
(\mathrm{g} / \text { plant })\end{array}$ & $\begin{array}{c}\text { Plant Dry } \\
\text { Weight } \\
(\mathrm{g} / \text { plant })\end{array}$ & $\begin{array}{c}\text { Fruit Fresh } \\
\text { Weight } \\
(\mathrm{g} / \text { plant })\end{array}$ & $\begin{array}{c}\text { Fruit Dry } \\
\text { Weight } \\
(\mathrm{g} / \text { plant })\end{array}$ & $\begin{array}{c}\text { Fruit Number } \\
\text { (number/plant) }\end{array}$ \\
\hline Aquifer & 1405 & 143.93 & 659.17 & 39.30 & 9.50 \\
\hline Control & 1258 & 119.89 & 463.33 & 28.13 & 8.50 \\
\hline $\begin{array}{c}\text { Differency } \\
(\%)\end{array}$ & 12 & 20 & 40 & 42 & 12 \\
\hline
\end{tabular}

Also plant biomass parameter in ATES and control greenhouses is given in table 2. Regarding this table plant fresh weight of ATES greenhouse is \%12 more than control greenhouse. Plant dry weight of ATES is \%20 more than control one. The biggest difference in both greenhouse is recorded weight of fruit. As we can see on table 2 $\%$ 40-42 ATES greenhouses vegetable more heavy than the control greenhouse. Also number of fruit is $\% 12$ more in ATES greenhouse then the control greenhouse.

\section{Results}

Regarding one year operating some economic items given in table 3 . All items in table 3 is calculated on 1000 $\mathrm{m}^{2}$ greenhouse basis. As we can see on table 3, two systems total finale cost is nearly same but we get average $\% 40$ more vegetable from ATES greenhouse (see Table 2). Also for this performance never use any fuel oil in ATES greenhouse. Just fan-coils and circulation pump use small amount of energy. Comparatively ATES greenhouse use nearly \%78 less energy than control greenhouse. Also during spring month we can able to make some cooling in ATES greenhouse. Cooling process data has not been evaluate yet.

Table 3: Some economic data of two systems

\begin{tabular}{|l|c|c|}
\hline & $\begin{array}{c}\text { Conventional Systems } \\
(\mathrm{x} 1.000)(\mathrm{TL})\end{array}$ & $\begin{array}{c}\text { ATES Systems } \\
(\mathrm{x} 1.000)(\mathrm{TL})\end{array}$ \\
\hline First Investment Cost & 20 & 30 \\
\hline Operation Cost & 13.6 & 4.9 \\
\hline Workmanship Cost & 0.9 & - \\
\hline Total & $\mathbf{3 4 . 5}$ & $\mathbf{3 4 , 9}$ \\
\hline
\end{tabular}

Also regarding "0" fossil burn usage in ATES greenhouse, system gain some environmental impact. Table 4 shows type of environmental gain from $1000 \mathrm{~m}^{2}$ greenhouse climatization with ATES.

Table 4: Environmental gain of ATES greenhouse

\begin{tabular}{|c|c|}
\hline Waste & Amount \\
\hline $\mathrm{CO}_{2}$ & 56 ton/year \\
\hline $\mathrm{SO}_{\mathrm{x}}$ & 0,4 ton/year \\
\hline $\mathrm{NO}_{\mathrm{x}}$ & 0,7 ton/year \\
\hline
\end{tabular}

\section{Acknowledge}

Authors greatly acknowledge to Scientific Technologic Research Council of Turkey (TÜBİTAK) and Çukurova University Academic Project Research Unit (Ç.Ü. BAP) for their support. 


\section{References}

Abak, K., Güler, H.Y., Baytorun, N. (1995) “A comparative study in heated and unheated plastic greenhouses of the mediterranean coastal region of Turkey: tomato plant growth, yield dynamics, crop quality and fuel consumption." Acta Horticulturae 412, 335-341.

Paksoy H.O., (2003) International Energy Agency Energy Conservation through Energy Storage Implementing Agreement (IEA ECES-IA) Annex 14 "Cooling in all climates with thermal energy storage" Subtask 1 General State of-the-art-report (http://cevre.cu.edu.tr/annex14/)

Paksoy H.O., Turgut B., Gürbüz Z., Evliya H., (2003) "First Aquifer Thermal Energy Storage (ATES) Plant in Turkey” Futurestock 2003 Congress. Warsaw, Poland, VI pp 77-83.

Andersson O., (2003) "Cooling with Underground Thermal Energy Storage Applications in Sweden" Futurestock 2003 Congress. Warsaw, Poland, VI pp 25-30.

Wu X., Ma J., Bink, B.,'nin (2000) “Aquifer Thermal Energy Storage Technique in China and Future Development” Terrastock 2000 Congress. Stuttgart Germany VI pp 69-73

Snijders A.,'nın (2000) “Lessons from 100 ATES projects The developments of aquifer storage in the Netherlands" Terrastock 2000 Congress. Stuttgart Germany VI pp 147-152

Dirven P., Gysen B., (2000) "Towards the growth of aquifer thermal energy storage in Flanders (Belgium) Terrastock 2000 Congress. Stuttgart Germany VI pp 30-36

Paksoy H.O., Andersson O., Abaci S., Evliya H., Turgut B. (2000) "Heating and Cooling of a Hospital Using Solar Energy Coupled with Seasonal Thermal Energy Storage in an Aquifer” RENEWABLE ENERGY 19 117-122 